\title{
The Metabolism of Baicalin in Rat and the Biological Activities of the Metabolites
}

\author{
Yi Wang, ${ }^{1,2}$ Jingyu Yang, ${ }^{1}$ Xian Li, ${ }^{1}$ and Jinhui Wang ${ }^{1}$ \\ ${ }^{1}$ Department of Natural Products Chemistry, Shenyang Pharmaceutical University, Liaoing 110016, China \\ ${ }^{2}$ Key Laboratory of Marine Drugs, Chinese Ministry of Education and School of Medicine and Pharmacy, Ocean University of China, \\ Qingdao 266003, China
}

Correspondence should be addressed to Yi Wang, wangyi0213@hotmail.com and Jinhui Wang, wangjh1972@vip.sina.com

Received 27 December 2011; Revised 15 February 2012; Accepted 6 March 2012

Academic Editor: Shuang-En Chuang

Copyright () 2012 Yi Wang et al. This is an open access article distributed under the Creative Commons Attribution License, which permits unrestricted use, distribution, and reproduction in any medium, provided the original work is properly cited.

Baicalin is one of the major bioactive constituents of Scutellariae Radix, but the biotransformation of it is poorly understood. In this paper, the metabolism of baicalin in rat was studied. Nine metabolites including one new compound were isolated and identified structurally. The plausible scheme for the biotransformation pathways of baicalin in the rats was deduced. And the main metabolites were evaluated for their antioxidation and anti-inflammation biological activities for the first time.

\section{Introduction}

Scutellariae Radix, the root of Scutellariae baicalensis Georgi, is widely used in traditional Chinese formulations. Baicalin (baicalein 7-O-glucuronide) is one of the major bioactive constituents of it, which possesses antiallergic, anti-inflammatory activity and antioxidation and has been used for the treatment of hepatitis, hyperlipidemia, and lipolysis [1].

It is well known that the process of drug metabolism affects therapeutic effects of drug. The biotransformation of baicalin is poorly understood, and that is due in part to difficulties that have been encountered in obtaining enough amounts to identify the structure of the metabolites and study the bioactivities of them. Although some works on the metabolism of baicalin have been investigated with the development of chromatography-spectrographic technology, because of the lack of metabolites quantitatively, many questions about the biological activities of the metabolites still remained after administration [2-5]. To gain additional insight into its metabolism and the biological activities of the metabolites, we isolated the metabolites from urine and feces of rats and identified their structures on the basis of physicochemical properties and spectroscopic data analysis. Nine metabolites including one new compound were obtained. At the same time, the antioxidation and antiinflammation biological activities of the metabolites were investigated. It is the first time that the metabolism and the bioactivities of the metabolites of baicalin were studied comprehensively.

\section{Materials and Methods}

2.1. Drugs. Baicalin was isolated and purified from Scutellariae Radix according to the method reported previously [6]. The crude drug was further purified with open ODS column, and the purity of the material exceeded $95 \%$ that was confirmed by HPLC.

2.2. Dosing Procedure. Seven-week old Wistar rats (five males and five females), weighing 180 to $210 \mathrm{~g}$, were used for the experiments. For isolation of metabolites, the rats were orally administered baicalin $(500 \mathrm{mg} / \mathrm{Kg})$ suspended in $0.5 \%$ CMC-Na solution with repeated dosing three times, then urine and feces were obtained by using a metabolic cage for $48 \mathrm{~h}$. All samples were stored below $-20^{\circ} \mathrm{C}$ until use.

2.3. Isolation of Metabolites. Urine samples from rats were combined, filtrated, and adjusted to $\mathrm{PH} 4$ with $\mathrm{HCl}$ and performed by chromatographic separation on a resin column eluting with water (part I), $\mathrm{C}_{2} \mathrm{H}_{5} \mathrm{OH} / \mathrm{H}_{2} \mathrm{O}(3: 7)$ (part II), 


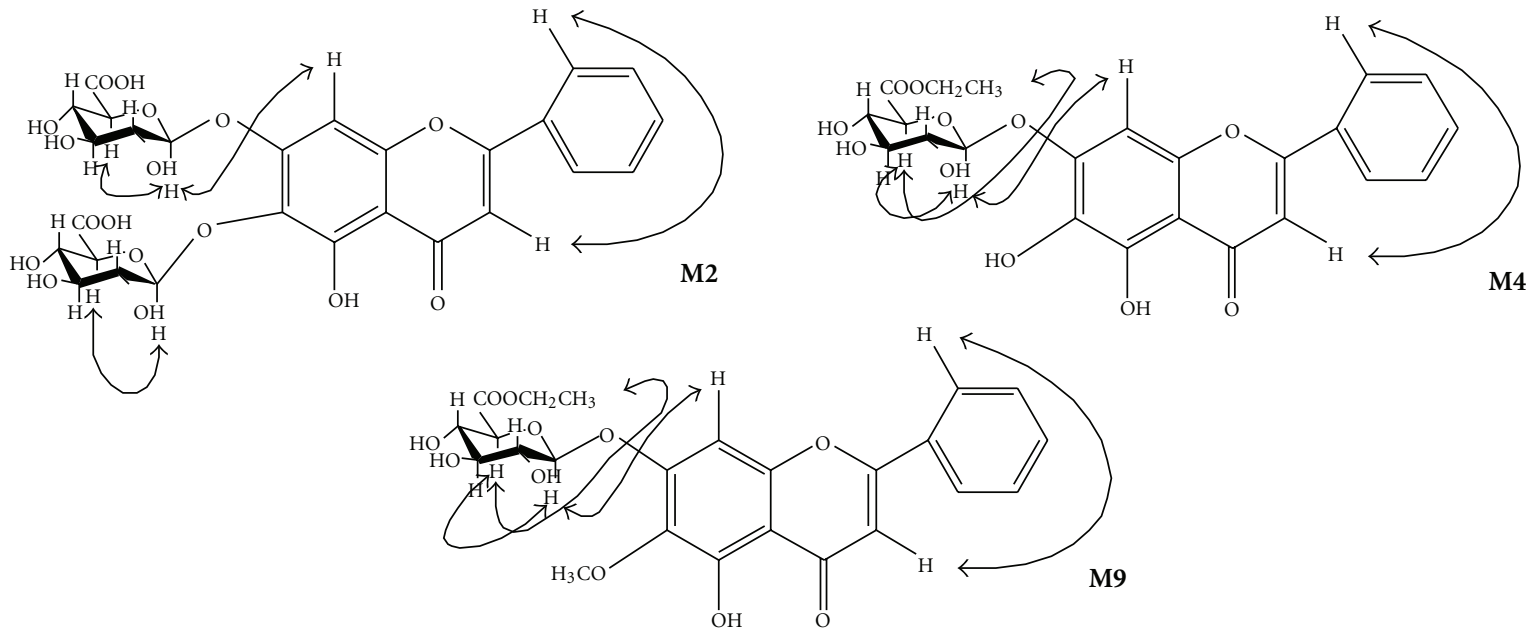

Figure 1: The NOE correlations on the NOESY spectra of metabolites M2, M4, and M9.

and $\mathrm{C}_{2} \mathrm{H}_{5} \mathrm{OH} / \mathrm{H}_{2} \mathrm{O}(9: 1)$ (part III). Part III was subjectedd to ODS column eluting with $\mathrm{CH}_{3} \mathrm{CN} / \mathrm{H}_{2} \mathrm{O}$ gradiently (from $95 \% \mathrm{H}_{2} \mathrm{O}$ to $65 \% \mathrm{H}_{2} \mathrm{O}$ ) to obtain the compounds M1(45 mg), M2(10 mg), M3(5 mg), and M4(3 mg). Preparative HPLC on ODS column was used to further purify $70 \%$ $\mathrm{H}_{2} \mathrm{O}$ fraction from ODS column with $\mathrm{CH}_{3} \mathrm{OH} / \mathrm{CH}_{3} \mathrm{CN} / \mathrm{H}_{2} \mathrm{O}$ (20:20:60) to obtain compounds $\mathbf{M} 7(2 \mathrm{mg})$ and $\mathbf{M 9}$ (3 mg), and $65 \% \mathrm{H}_{2} \mathrm{O}$ fraction from ODS column was also chromatographed on preparative $\mathrm{HPLC}$ with $\mathrm{CH}_{3} \mathrm{OH} / \mathrm{H}_{2} \mathrm{O}(70: 60)$ to obtain compounds M6(3 mg) and M8(3 mg). Preparative TLC on silica gel was used to further purify $75 \% \mathrm{H}_{2} \mathrm{O}$ fraction from ODS column to obtain compound M5(25 mg).

Feces samples from rats were combined, suspended in the water and adjusted to $\mathrm{PH} 7$ with $\mathrm{NaHCO}_{3}$-saturated aqueous solution, and then filtrated. The filtrate was adjusted to $\mathrm{PH} 4$ with $\mathrm{HCl}$ and subjected to a resin column eluting with water (part I), $\mathrm{C}_{2} \mathrm{H}_{5} \mathrm{OH}-\mathrm{H}_{2} \mathrm{O}(3: 7)$ (part II), and $\mathrm{C}_{2} \mathrm{H}_{5} \mathrm{OH}-\mathrm{H}_{2} \mathrm{O}(9: 1)$ (part III). Then part II and part III were combined and subjected to Sephadex LH-20 eluting with $\mathrm{C}_{2} \mathrm{H}_{5} \mathrm{OH}-\mathrm{H}_{2} \mathrm{O}$ (from $100 \% \mathrm{H}_{2} \mathrm{O}$ to $30 \% \mathrm{H}_{2} \mathrm{O}$ ): $\mathrm{C}_{2} \mathrm{H}_{5} \mathrm{OH}-$ $\mathrm{H}_{2} \mathrm{O}(2: 8)$ fraction from $\mathrm{LH}-20$ gave $\mathrm{M1}(20 \mathrm{mg}) ; \mathrm{C}_{2} \mathrm{H}_{5} \mathrm{OH}-$ $\mathrm{H}_{2} \mathrm{O}$ (35:65) fraction gave $\mathbf{M} 5$ (32 mg); $\mathrm{C}_{2} \mathrm{H}_{5} \mathrm{OH}-\mathrm{H}_{2} \mathrm{O}(4: 6)$ fraction was further purified by preparative HPLC on an ODS column eluting with $\mathrm{CH}_{3} \mathrm{OH}-\mathrm{H}_{2} \mathrm{O}(2: 8)$ and gave M6(2 mg) and M8(2 mg).

\subsection{Identification of Baicalin and Metabolites}

2.4.1. General Experimental Procedures. Semipreparative high-performance liquid chromatography was performed on an ODS column (YMC-pack ODS-A, $10 \times 250 \mathrm{~mm}, 5 \mu \mathrm{m}$ ) at a flow rate of $3 \mathrm{~mL} / \mathrm{min}$. Analyses of compounds by electrospray ionization mass (ESI-MS) spectroscopy were conducted with a Thermo-Finnigan LCQ quadrupole ion-trap mass spectrometer (Thermo, San Jose, CA). Nuclear magnetic resonance (NMR) spectroscopy was performed on a BRUKERAPX-300 to obtain ${ }^{1} \mathrm{H}(300 \mathrm{MHz})$ and ${ }^{13} \mathrm{C}(75 \mathrm{MHz})$ spectra of the pigment in dimethyl sulfoxided-6 (DMSO-d6).

\subsubsection{Metabolites Data}

M2: yellow powder. ESI-MS m/z: $645.1[\mathrm{M}+\mathrm{Na}]^{+}, 623.1$ $[\mathrm{M}+\mathrm{H}]^{+}, 621.1[\mathrm{M}-\mathrm{H}]^{-}, 621.1[\mathrm{M}-\mathrm{H}]^{-}, 445.0$ [M-glcA-H $^{-}$. ${ }^{1} \mathrm{H}-\mathrm{NMR}\left(300 \mathrm{MHz}, \mathrm{DMSO}-\mathrm{d}_{6}\right): \delta 7.61\left(2 \mathrm{H}, \mathrm{m}, \mathrm{H}-3^{\prime}, 5^{\prime}\right)$, $\left.7.60\left(1 \mathrm{H}, \mathrm{m}, \mathrm{H}-4^{\prime}\right), 8.10\left(2 \mathrm{H}, \mathrm{d}, J=6.0 \mathrm{~Hz}, \mathrm{H}-2^{\prime}, 6^{\prime}\right)\right], 7.12$ (1H, s, H-8), 7.07 (1H, s, H-3), 12.89 (1H, s, HO-5), 5.27 $(1 \mathrm{H}, \mathrm{d}, J=7.4 \mathrm{~Hz}, 7$-glcA-1), $4.97(1 \mathrm{H}, \mathrm{d}, J=7.3 \mathrm{~Hz}, 6-$ glcA-1), 4.00 (1H, d, $J=9.5 \mathrm{~Hz}, 7$-glcA-5), 3.57 (1H, d, $J=$ 9.6 Hz, 6-glcA-5), 3.1-3.4 (m). NOESY: given as in Figure 1. M3: yellow powder. ESI-MS m/z: $483.1[\mathrm{M}+\mathrm{Na}]^{+}, 459.0[\mathrm{M}-$ $\mathrm{H}]^{-}, 445.0\left[\mathrm{M}-\mathrm{CH}_{3}-\mathrm{H}\right]^{-} .{ }^{1} \mathrm{H}-\mathrm{NMR}\left(300 \mathrm{MHz}, \mathrm{DMSO}-\mathrm{d}_{6}\right)$ : $\delta 7.62\left(2 \mathrm{H}, \mathrm{m}, \mathrm{H}-3^{\prime}, 5^{\prime}\right), 7.60\left(1 \mathrm{H}, \mathrm{m}, \mathrm{H}-4^{\prime}\right), 8.08(2 \mathrm{H}, \mathrm{d}$, $\left.\left.J=6.0 \mathrm{~Hz}, \mathrm{H}-2^{\prime}, 6^{\prime}\right)\right], 7.06(1 \mathrm{H}, \mathrm{s}, \mathrm{H}-8), 7.02(1 \mathrm{H}, \mathrm{s}, \mathrm{H}-$ 3), 12.57(1H, s, HO-5), $8.29(1 \mathrm{H}, \mathrm{s}, \mathrm{HO}-6), 5.29(1 \mathrm{H}, \mathrm{d}$, $J=6.9 \mathrm{~Hz}, 7-$ glcA-1 $), 4.23(1 \mathrm{H}, \mathrm{d}, J=9.3 \mathrm{~Hz}, 7-$ glcA-5), 3.1-3.4 (m).

M4: yellow powder. ESI-MS m/z: $497.1[\mathrm{M}+\mathrm{Na}]^{+}, 475.1$ $[\mathrm{M}+\mathrm{H}]^{+}, 473.0[\mathrm{M}-\mathrm{H}]^{-}, 445.0\left[\mathrm{M}-\mathrm{CH}_{3} \mathrm{CH}_{2}-\mathrm{H}\right] .{ }^{1} \mathrm{H}-\mathrm{NMR}$ $\left(300 \mathrm{MHz}, \mathrm{DMSO}_{-} \mathrm{d}_{6}\right): \delta 7.60\left(2 \mathrm{H}, \mathrm{m}, \mathrm{H}-3^{\prime}, 5^{\prime}\right), 7.59(1 \mathrm{H}, \mathrm{m}$, H-4' $), 8.08$ (2H, d, J = 6.0 Hz, H-2' $\left.6^{\prime}\right), 7.07$ (1H, s, H-8), 7.02 (1H, s, H-3), 12.59 (1H, s, HO-5), 8.65 (1H, s, HO-6). $5.28(1 \mathrm{H}, \mathrm{d}, J=7.2 \mathrm{~Hz}, 7$-glcA-1 $), 4.18(1 \mathrm{H}, \mathrm{d}, J=9.6 \mathrm{~Hz}$, 7-glcA-5), 3.1-3.4 (m), $1.21\left(3 \mathrm{H}, \mathrm{t}, J=7.2 \mathrm{~Hz}, \mathrm{CH}_{3}\right), 4.11$ $\left(2 \mathrm{H}, \mathrm{m}, \mathrm{CH}_{2}\right)$. NOESY: given as in Figure 2.

M6: yellow powder. ESI-MS m/z: $307.0[\mathrm{M}+\mathrm{Na}]^{+}, 282.9[\mathrm{M}-$ $\mathrm{H}]^{-} .{ }^{1} \mathrm{H}-\mathrm{NMR}\left(300 \mathrm{MHz}, \mathrm{DMSO}-\mathrm{d}_{6}\right): \delta 7.61(2 \mathrm{H}, \mathrm{m}, \mathrm{H}-$ $\left.3^{\prime}, 5^{\prime}\right), 7.61\left(1 \mathrm{H}, \mathrm{m}, \mathrm{H}-4^{\prime}\right), 8.07\left(2 \mathrm{H}, \mathrm{d}, J=6.0 \mathrm{~Hz}, \mathrm{H}-2^{\prime}, 6^{\prime}\right)$, $6.25(1 \mathrm{H}, \mathrm{s}, \mathrm{H}-8), 6.96(1 \mathrm{H}, \mathrm{s}, \mathrm{H}-3), 12.51$ (1H, s, HO-5), 8.4 $(1 \mathrm{H}, \mathrm{s}, \mathrm{HO}-6), 3.80\left(3 \mathrm{H}, \mathrm{s}, \mathrm{OCH}_{3}\right)$.

M7: yellow powder. ESI-MS m/z: $874.8[3 \mathrm{M}+\mathrm{Na}]^{+}, 590.9$ $[2 \mathrm{M}+\mathrm{Na}]^{+}, 307.0[\mathrm{M}+\mathrm{Na}]^{+}, 282.9[\mathrm{M}-\mathrm{H}]^{-} .{ }^{1} \mathrm{H}-\mathrm{NMR}$ $\left(300 \mathrm{MHz}, \mathrm{DMSO}-\mathrm{d}_{6}\right): \delta 7.63\left(2 \mathrm{H}, \mathrm{m}, \mathrm{H}-3^{\prime}, 5^{\prime}\right), 7.62(1 \mathrm{H}$, m, H-4' $), 8.07\left(2 \mathrm{H}, \mathrm{m}, \mathrm{H}-2^{\prime}, 6^{\prime}\right), 6.32(1 \mathrm{H}, \mathrm{s}, \mathrm{H}-8), 7.02(1 \mathrm{H}$, s, H-3), 12.51 (1H, s, HO-5), 10.8 (1H, s, HO-7), $3.86(3 \mathrm{H}$, $\left.\mathrm{s}, \mathrm{OCH}_{3}\right)$.

M8: yellow powder. ESI-MS m/z: $307.1[\mathrm{M}+\mathrm{Na}]^{+}, 282.9$ $[\mathrm{M}-\mathrm{H}]^{-} .{ }^{1} \mathrm{H}-\mathrm{NMR}\left(300 \mathrm{MHz}, \mathrm{DMSO}-\mathrm{d}_{6}\right): \delta 7.57(2 \mathrm{H}, \mathrm{m}$, 


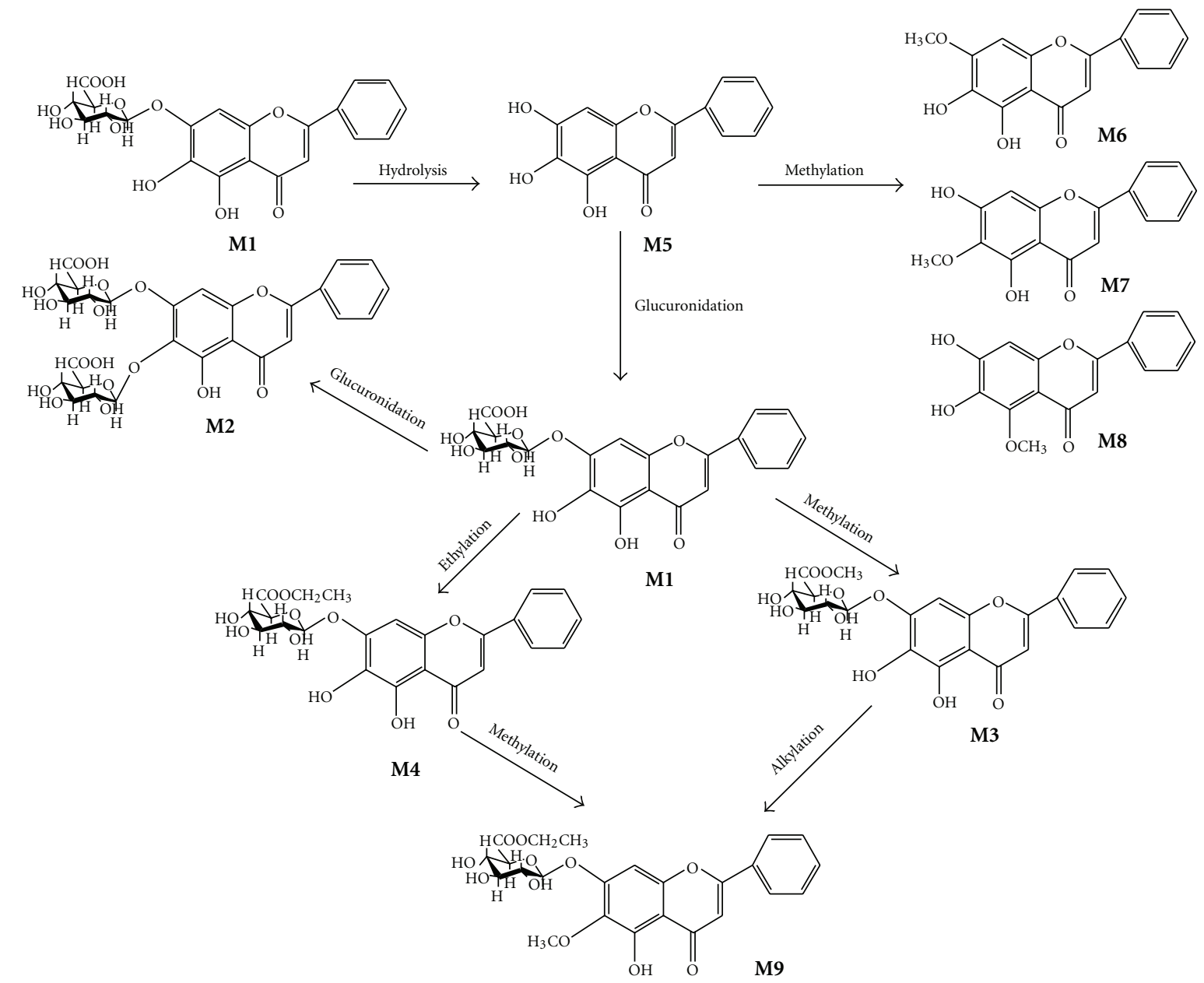

Figure 2: The plausible scheme for the biotransformation pathways of baicalin in the rats.

H-3', $\left.5^{\prime}\right), 7.57\left(1 \mathrm{H}, \mathrm{m}, \mathrm{H}-4^{\prime}\right), 8.37\left(2 \mathrm{H}, \mathrm{m}, \mathrm{H}-2^{\prime}, 6^{\prime}\right), 6.54$ (1H, s, H-8), 6.19 (1H, s, H-3), $8.4(1 \mathrm{H}, \mathrm{s}, \mathrm{HO}-6), 3.72(3 \mathrm{H}$, $\left.\mathrm{s}, \mathrm{OCH}_{3}\right)$.

M9: yellow powder. ESI-MS m/z: $511.1[\mathrm{M}+\mathrm{Na}]^{+}, 523.0$ $[\mathrm{M}+\mathrm{Cl}]^{-}, 487.0[\mathrm{M}-\mathrm{H}]^{-} .{ }^{1} \mathrm{H}-\mathrm{NMR}\left(300 \mathrm{MHz}, \mathrm{DMSO}-\mathrm{d}_{6}\right)$ : $\delta 7.63\left(2 \mathrm{H}, \mathrm{m}, \mathrm{H}-3^{\prime}, 5^{\prime}\right), 7.62\left(1 \mathrm{H}, \mathrm{m}, \mathrm{H}-4^{\prime}\right), 8.09(2 \mathrm{H}, \mathrm{m}$, H-2' $\left.6^{\prime}\right), \delta 7.13(1 \mathrm{H}, \mathrm{s}, \mathrm{H}-3), 7.07$ (1H, s, H-8), $12.83(1 \mathrm{H}$, s, HO-5). $\delta 5.36(1 \mathrm{H}, \mathrm{d}, J=6.9 \mathrm{~Hz}, 7$-glcA-1 $), 4.18(1 \mathrm{H}$, $\mathrm{d}, J=9.6 \mathrm{~Hz}, 7$-glcA-5), 3.1-3.4 (m). $3.78\left(3 \mathrm{H}, \mathrm{s}, \mathrm{OCH}_{3}\right)$, $1.20\left(3 \mathrm{H}, \mathrm{t}, J=6.6 \mathrm{~Hz}, \mathrm{CH}_{3}\right)$, and $4.14,4.11$ (each $1 \mathrm{H}$, dd, $\left.J=15.0,6.6 \mathrm{~Hz}, \mathrm{CH}_{2} \mathrm{O}\right)$. NOESY: given as in Figure 3 .

\subsection{Biological Activities of the Metabolites}

2.5.1. Antioxidation. Livers were obtained from rats and disposed of the blood. Twenty g of the livers was divided into pieces and prepared into homogenate with physiological salt solution by refiner about $8000 \mathrm{r} / \mathrm{min}$ and then added physiological salt solution to $400 \mathrm{~mL}$ to be $5 \%$ tissue homogenate. Saline was used for blank; extract of ginkgo biloba leaves injection $250 \mathrm{mg} / \mathrm{mL}$ was used for positive control; baicalin (M1) and the metabolites baicalein (M5) and baicalein 6,7di-O- $\beta$-glucopyranuronoside (M2) were also analyzed.
All the numbered tubes were added with $1.5 \mathrm{~mL} 5 \%$ tissue homogenate, reference substance flavonoids extracts of ginkgo, and metabolites of baicalin. Negative control was physiological saline. All the tubes were incubated at $37^{\circ} \mathrm{C}$ for $1 \mathrm{~h}$, and $1.5 \mathrm{~mL} 20 \%$ trichloroacetic acid was added. All the tubes were mixed, and standing for $10 \mathrm{~min}$, centrifuged at $3000 \mathrm{rpm}$ for $10 \mathrm{~min}$. The supernatant was added with $0.67 \%$ thiobarbituric acid and heated in boring water for $10 \mathrm{~min}$. The cool solution was tested on spectrophotometer at $532 \mathrm{~nm}$ to obtain data. Based on the standard curve of malonaldehyde bis(diethyl acetal), malonaldehyde $(\mathrm{nmol} / \mathrm{mL})$ was calculated by multiplying parameter 68.89.

2.5.2. Effect on LPS-Induced NO Yielding. Wistar rats (weight 200 to $250 \mathrm{~g}$ ) were used for experiments. The rats were decapitated and treated with celiac injection with $15 \mathrm{~mL}$ RPMI1640 culture medium. Irrigating solution was centrifuged at $1000 \mathrm{r} / \mathrm{min}$ for $10 \mathrm{~min}$. The supernatant was discarded. The deposition was suspended in RPMI1640 culture medium (10\% FBS) and incubated for $1 \mathrm{~h}$, and nonadherent cell is discarded. Cells on the wall were washed by RPMI1640 culture medium (10\% FBS), dyed by nigrosine, and counted on blood counting chamber. The cell density was adjusted to 


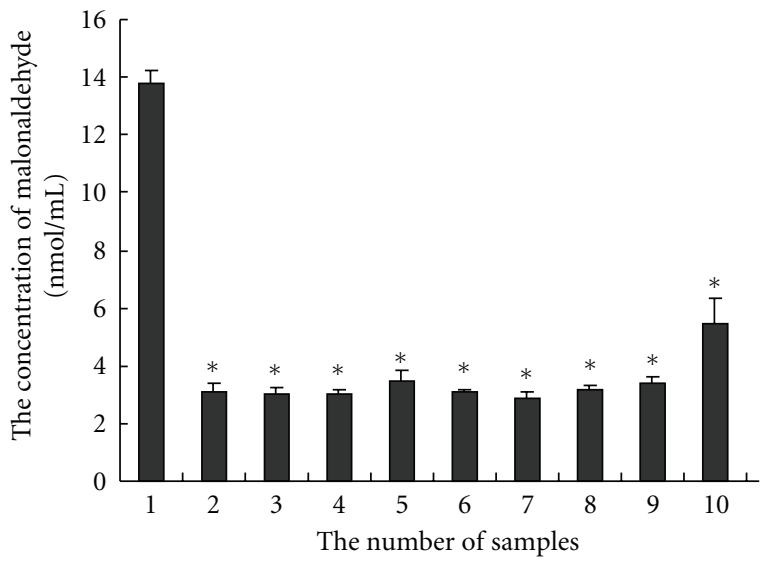

FIGURE 3: The effects of baicalin (M1) and the metabolites baicalein (M5) and baicalein 6,7-di-O- $\beta$-glucopyranoside (M2) on liver lipid peroxide of rats. (1, saline; 2 , extract of ginkgo biloba leaves injec tion $250 \mathrm{mg} / \mathrm{mL}$; 3, M1 $40 \mathrm{mg} / \mathrm{mL} ; 4$, M1 $20 \mathrm{mg} / \mathrm{mL}$; 5, M1 $10 \mathrm{mg} / \mathrm{mL}$; 6, M5 $20 \mathrm{mg} / \mathrm{mL}$; , M5 $10 \mathrm{mg} / \mathrm{mL} ; 8$, M5 $5 \mathrm{mg} / \mathrm{mL} ; 9$, M2 $40 \mathrm{mg} / \mathrm{mL}$; 10, M2 $20 \mathrm{mg} / \mathrm{mL} ; 11, \mathbf{M} 210 \mathrm{mg} / \mathrm{mL}$; *, $P<0.01 \mathrm{t}$ test compared with saline group).

$60 \times 10^{4}$ cells $/ \mathrm{cm}^{2}$. The cells were incubated overnight. The culture medium was changed to serum-free medium. LPS (lipopolysaccharide), different metabolites of baicalin, and L-NAME (NO synthase inhibitor) were added. After $24 \mathrm{~h}$ of incubation, the contents of $\mathrm{NO}_{2}{ }^{-}$in medium were tested with Griess colorimetry. Experimental results were analyzed statistically with SPSS software. L-NAME was used for positive control; the metabolites, baicalein 6,7-di-O- $\beta$ glucopyranuronoside (M2), baicalein 7-O- $\beta$-D-glucopyranuronoside methyl ester (M3), baicalein (M5), and 7-O-methyl-baicalein (M6), were also analyzed.

\section{Results and Discussion}

3.1. The Metabolism of Baicalin in Rats. Baicalin was orally administered to rats. The collected urine and feces samples were extracted and analyzed as described in experimental part. In addition to baicalin, a total of 8 metabolites including baicalin (M1), baicalein 6,7-di-O- $\beta$-D-glucopyranuronoside (M2), baicalein 7-O- $\beta$-D-glucopyranuronoside methyl ester (M3), baicalein 7-O- $\beta$-D-glucopyranuronoside ethyl ester (M4), baicalein (M5), 7-O-methyl-baicalein (M6), 6-Omethyl-baicalein (M7), 5-O-methyl-baicalein (M8), 6-Omethyl-baicalein-7-O- $\beta$-D-glucopyranuronoside ethyl ester (M9) were found present in urine and 4 metabolites (M1, M5, M6, and M8) in feces. The structures of metabolites were elucidated by a combination analysis of their chromatographic behavior, analysis of MS, ${ }^{1} \mathrm{HNMR}$ data, NOESY data, and spectral comparison to several reference substances.

Metabolites M1 and M5. Compared with reference substances, M1 and M5 have the same chromatographic behavior and NMR data. So M1 and M5 were identified as baicalin and baicalein, respectively.
Metabolites M2. Compared with baicalin, there are two groups of the data of glucuronide on the ${ }^{1} \mathrm{HNMR}$ spectrum of $\mathbf{M} 2[\delta: 5.27(1 \mathrm{H}, \mathrm{d}, J=7.4 \mathrm{~Hz}, 7$-glcA-1 $), 4.97(1 \mathrm{H}, \mathrm{d}$, $J=7.3 \mathrm{~Hz}, 6$-glcA-1), $4.00(1 \mathrm{H}, \mathrm{d}, J=9.5 \mathrm{~Hz}, 7$-glcA-5 $)$, $3.57(1 \mathrm{H}, \mathrm{d}, J=9.6 \mathrm{~Hz}, 6$-glcA-5), 3.1-3.4 $(\mathrm{m})]$, and the chemical shift of $\delta 8.6(1 \mathrm{H}, \mathrm{s}, \mathrm{HO}-6)$ disappeared, but $\delta$ $12.56(1 \mathrm{H}, \mathrm{s}, \mathrm{HO}-5)$ still can be observed. At the same time combined with NOESY spectrum (Figure 1), the correlation between the anomeric proton of glucuronide $(\delta 5.27)$ and the proton of position $8(\delta 7.12)$ was observed. All these showed that there were two glucuronides at the position of C-6 and C-7. On the ESI-MS, the m/z: $645.1[\mathrm{M}+\mathrm{Na}]^{+}$, $623.1[\mathrm{M}+\mathrm{H}]^{+}, 621.1[\mathrm{M}-\mathrm{H}]^{-}, 621.1[\mathrm{M}-\mathrm{H}]^{-}, 445.0[\mathrm{M}-$ glcA-H $]^{-}$was accordant. The chemical structure of $\mathbf{M} 2$ was determined as baicalein 6,7-di-O- $\beta$-glucopyranuronoside.

Metabolites M3 and M4. Compared with the ${ }^{1}$ HNMR spectrum of baicalin, $\mathbf{M} 3$ revealed considerable similarity that there was one group of the data of glucuronide but differed in one proton of methyl $\delta 3.61(3 \mathrm{H}, \mathrm{s})$, and the chemical shift of the proton at position 5 of the glucuronide was shifted to downfield by 0.6 , which suggested the existence of glucopyranuronoside methyl ester. So M3 was determined as baicalein 7-O- $\beta$-D-glucopyranuronoside methyl ester. On the ESI-MS, the $\mathrm{m} / \mathrm{z}: 483.1[\mathrm{M}+\mathrm{Na}]^{+}, 459.0[\mathrm{M}-\mathrm{H}]^{-}, 445.0\left[{\left.\mathrm{M}-\mathrm{CH}_{3}-\mathrm{H}\right]^{-}}^{-}\right.$ was accordant. M4 showed very similar ${ }^{1} \mathrm{HNMR}$ spectrum with M3, except one group of ethyl data $[\delta: 1.21(3 \mathrm{H}, \mathrm{t}, J=$ $\left.\left.7.2 \mathrm{~Hz}, \mathrm{CH}_{3}\right), 4.11\left(2 \mathrm{H}, \mathrm{m}, \mathrm{CH}_{2}\right)\right]$. Combined with NOESY spectrum (Figure 1), there was a correlation between the anomeric proton of one glucuronide $(\delta 5.28)$ and the proton of position 8 ( $\delta 7.07)$, so the positions of glucuronide can be determined that was position 7 . The correlation between the proton at position 5 of the glucuronide $(\delta 4.18)$ and the methyl proton $(\delta 1.21)$ was also observed. Thus, the structure of M4 was determined as baicalein 7-O- $\beta$-D-glucopyranuronoside ethyl ester.

Metabolites M6, M7, and M8. Compared with the ${ }^{1} \mathrm{HNMR}$ spectrum of baicalin, there was no glucuronide signal but one methyl proton in these three metabolites. The molecular weight of them $\left(\mathrm{m} / \mathrm{z}: 307.1[\mathrm{M}+\mathrm{Na}]^{+}, 282.9[\mathrm{M}-\mathrm{H}]^{-}\right)$also showed $\mathrm{m} / \mathrm{z} 14$ more than baicalin. All of them showed A2A'B2 coupled system for ring-C without any substituent that was the same as baicalin. On the ${ }^{1} \mathrm{HNMR}$ spectrum of M6, OH-5 and OH-6 still can be observed, but OH-7 disappeared, and one $\mathrm{OCH}_{3}$ was observed, and at the same time the chemical shift of the proton of position 8 was shifted to high field by 0.4 , compared with baicalein (M5). Therefore, the chemical structure of $\mathbf{M} \mathbf{6}$ was determined as 7-O-methylbaicalein. Compared with M5, $\delta 12.51(1 \mathrm{H}, \mathrm{s}, \mathrm{HO}-5)$ and $\delta$ $10.8(1 \mathrm{H}, \mathrm{s}, \mathrm{HO}-7)$ still can be observed, but the proton signal of $\mathrm{HO}-6$ was substituted by $\delta 3.86\left(3 \mathrm{H}, \mathrm{s}, \mathrm{OCH}_{3}-6\right)$ on $\mathbf{M} 7$. The chemical structure of $\mathbf{M} 7$ was determined as 6-Omethyl-baicalein compared with reference [7]. M8 had the different retention characteristic with $\mathbf{M 6}$ and M7. On the ${ }^{1} \mathrm{HNMR}$ spectrum of M8, the proton signal of HO-5 was substituted by $\delta 3.72\left(3 \mathrm{H}, \mathrm{s}, \mathrm{OCH}_{3}\right)$, and the chemical shift of the proton of position 8 shifted to high field by 0.3 , so 
the chemical structure of $\mathbf{M 8}$ was determined as 5-O-methylbaicalein.

Metabolite M9. Compared with baicalin, M9 revealed considerable similarity, but differences were that one group of ethoxy data $\left[\delta 1.20\left(3 \mathrm{H}, \mathrm{t}, J=6.6 \mathrm{~Hz}, \mathrm{CH}_{3}\right)\right.$ and $\delta 4.14$, 4.11 (each $1 \mathrm{H}, \mathrm{dd}, J=15.0,6.6 \mathrm{~Hz}, \mathrm{CH}_{2} \mathrm{O}$ ) ], one methyl proton $(\delta 3.78(3 \mathrm{H}, \mathrm{s}, \mathrm{CH} 3))$, but the active proton of $\mathrm{OH}$ at position 6 disappeared. The chemical shift of the proton at position 5 of the glucuronide shifted to downfield by 0.5 , and the proton at position 5 of glucuronide $(\delta 4.18)$ had a correlation with the methyl proton of oxyethyl group $(\delta$ 1.20) combined with NOESY spectrum (Figure 1), so this metabolite can be determined as one glucopyranuronoside ethyl ester. On NOESY, the correlation between the anomeric proton of the glucuronide $(\delta 5.36)$ and the proton of position 8 ( $\delta$ 7.07) was observed, so the positions of glucuronide can be determined to be position 7, and the methyl proton was at position 6 . On the ESI-MS, the $\mathrm{m} / \mathrm{z}: 511.1[\mathrm{M}+\mathrm{Na}]^{+}$, $523.0[\mathrm{M}+\mathrm{Cl}]^{-}, 487.0[\mathrm{M}-\mathrm{H}]^{-}$was also accordant. Thus, the chemical structure of $\mathbf{M 9}$ was determined as 6-O-methylbaicalein-7-O- $\beta$-D-glucopyranuronoside ethyl ester. To our knowledge, this compound was the first time to be isolated and identified.

Based on the structures of these metabolites, a plausible scheme for the biotransformation pathways of baicalin in the rats was shown in Figure 2. The results of the present study demonstrated that the major metabolites of baicalin were baicalin, baicalein, and glucuronide after oral administration, and at the same time, small amount of alkylated products were also found, which was a little different from [4]. This may be for the more alkylation reacted on glucuronides and aglycone with longer time. The baicalin is very difficult to be absorbed into blood directly [8]. In the gastrointestinal tracts of rats, baicalein was hydrolyzed into baicalein by $\beta$-glucuronidase produced by intestinal bacteria. Thus, baicalein can be easily absorbed into blood. Through enterohepatic circulation, baicalein was transformed to glucuronides and then modified to kinds of alkylated glucuronides to demonstrate bioactivities.

3.2. The Biological Activities of the Metabolites. The effects of baicalin (M1) and the metabolites (M5), (M2) on liver lipid peroxide of rats were studied as shown in Figure 3. As can be seen, baicalin (M1), baicalein (M5), and baicalein 6,7-di$O-\beta$-glucopyranuronoside (M2) have more stronger antioxidation than positive control, flavonoids extract of ginkgo. Baicalein (M5) was even much stronger.

Figure 4 showed the effect of the metabolites (M5), (M2), (M3), and (M6) on NO yielded by macrophage. As can be seen, LPS $(10 \mu \mathrm{g} / \mathrm{mL})$ induced macrophage to yield NO in $24 \mathrm{~h}$, and positive control L-NAME can inhibit NO yielding significantly. Metabolites baicalein (M5) and baicalein 6,7di-O- $\beta$-glucopyranuronoside (M2) had significantly inhibiting effect on NO yielding induced by LPS within the range of the test content. Baicalein 7-O- $\beta$-D-glucopyranuronoside methyl ester (M3) and 7-O-methyl-baicalein (M6) had no

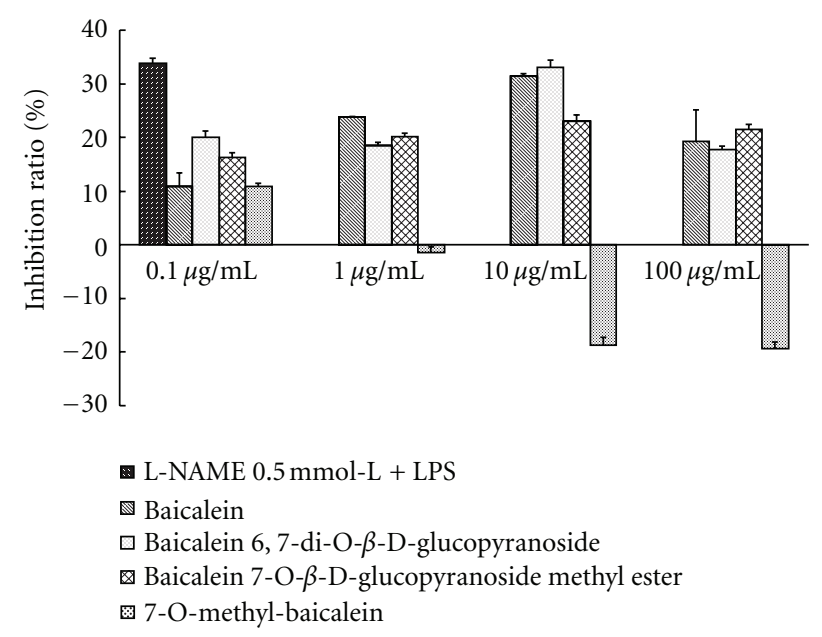

FIGURE 4: The inhibition of metabolites on LPS-induced NO yielding.

inhibiting effect on NO yielding induced by LPS within the range of the test content.

As described above, baicalin was metabolized to baicalein, glucuronide, and methylated products though metabolism of intestinal bacteria and enterohepatic circulation. Although studies on the metabolism of drugs have been investigated with the development of LC-MS, the bioactivities on metabolites are still lacking of investigation. The results of bioactive experiments of these metabolites in our experiments demonstrated that baicalein and glucuronide showed significant potential on antioxidation and affections on LPSinduced NO yielding compared with reference substance. However, when substituents were replaced by alkyl, bioactivity was depressed. To our knowledge, this is the first time that the metabolites of baicalin were investigated on the antioxidation and anti-inflammation biological activities. These results suggested though baicalein had good biological availability, it could not be used for its instability, while glucuronides of baicalein will be the perspective lead compounds for their good stability and bioactivities.

\section{Acknowledgments}

The authors thank Mr. Wenjun Pan of Shenyang Pharmaceutical University for his experimental assistance. This work is partly supported by Shandong Provincial Natural Science Foundation (no. ZR2009CQ014) and Scientific Research Foundation for the Returned Overseas Chinese Scholars, State Education Ministry (no.[2010]1174).

\section{References}

[1] M. Y. Lai, S. L. Hsiu, S. Y. Tsai, Y. C. Hou, and P. D. Lee Chao, "Comparison of metabolic pharmacokinetics of baicalin and baicalein in rats," Journal of Pharmacy and Pharmacology, vol. 55, no. 2, pp. 205-209, 2003.

[2] F. Zuo, Z. M. Zhou, M. Z. Yan et al., "Metabolism of constituents in Huangqin-Tang, a prescription in traditional Chinese 
medicine, by human intestinal flora," Biological and Pharmaceutical Bulletin, vol. 25, no. 5, pp. 558-563, 2002.

[3] F. Zuo, Z. M. Zhou, Q. Zhang et al., "Pharmacokinetic study on the multi-constituents of Huangqin-Tang decoction in rats," Biological and Pharmaceutical Bulletin, vol. 26, no. 7, pp. 911919, 2003.

[4] N. P. Feng, B. Di, and W. Y. Liu, "Comparison of the metabolism of baicalin in rats orally administered with Radix scutellariae extract and Shuang-Huang-Lian extract," Chemical and Pharmaceutical Bulletin, vol. 53, no. 8, pp. 978-983, 2005.

[5] J. R. Li, F. Zuo, L. Zhang, N. Norio, and H. Masao, "Study on the metabolism of the precipitation of Xiexin decoction in rats I," Zhongguo Zhongyao Zazhi, vol. 30, no. 21, pp. 1673-1676, 2005.

[6] Q. S. Lin, Zhong Cao Yao Cheng FenHua Xue, People's Medical Publishing House, Beijing, China, 1980.

[7] I. G. Collado, F. A. Macias, G. M. Massanet, and F. R. Luis, "Flavonoids from Centaurea clementei," Journal of Natural Products, vol. 48, no. 5, pp. 819-822, 1985.

[8] T. Akao, K. Kawabata, E. Yanagisawa et al., "Balicalin the predominant flavone glucoronide of Scutellariae Radix is absorbed from the rat gastrointestinal tract as the aglycone and restored to its original form," Journal of Pharmacy and Pharmacology, vol. 52, no. 12, pp. 1563-1568, 2000. 


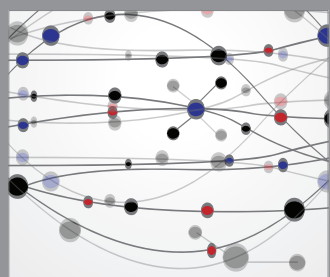

The Scientific World Journal
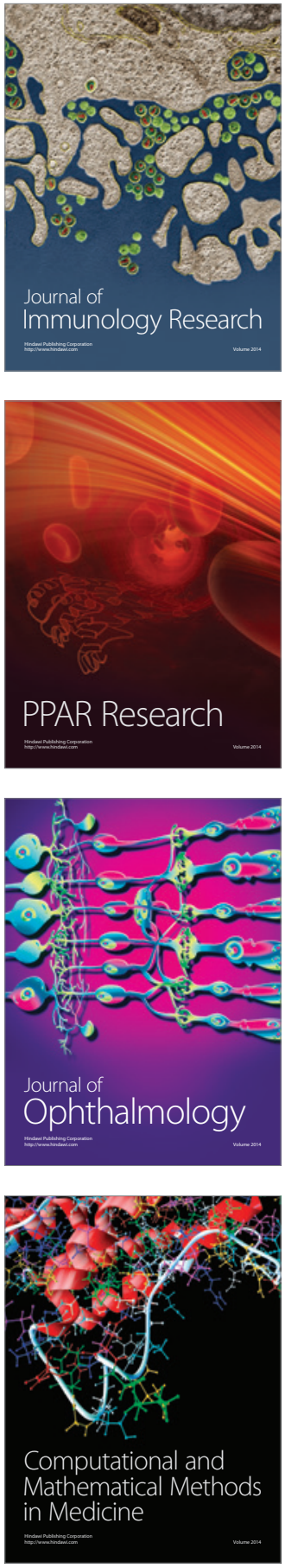

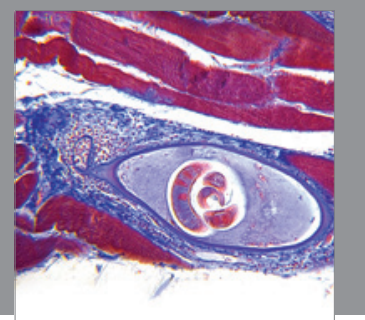

Gastroenterology

Research and Practice
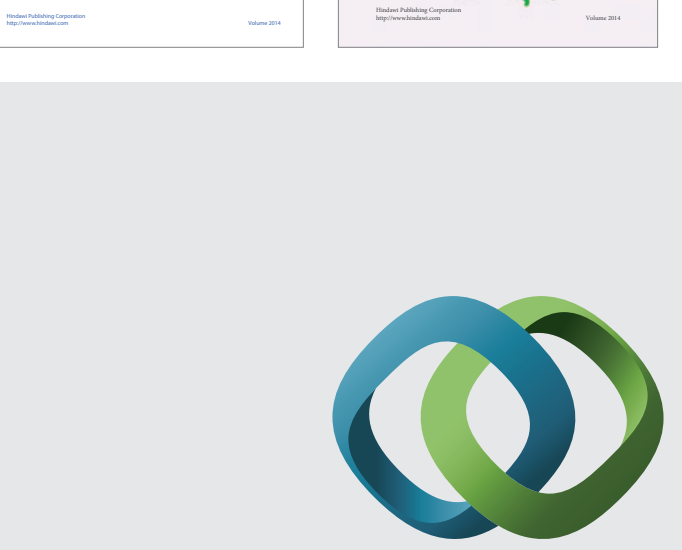

\section{Hindawi}

Submit your manuscripts at

http://www.hindawi.com
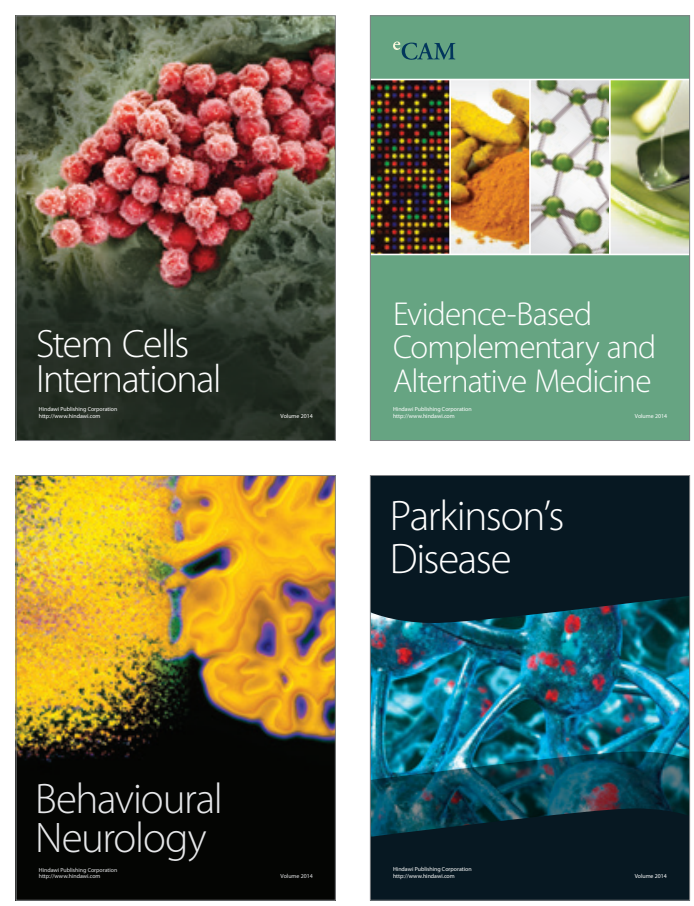

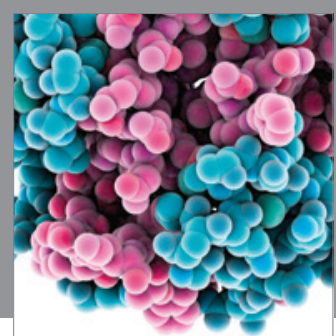

Journal of
Diabetes Research

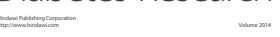

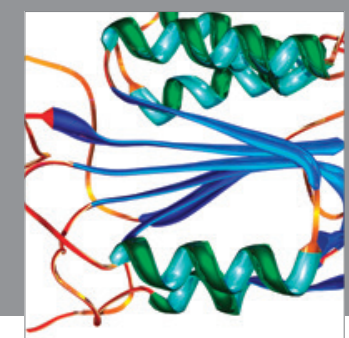

Disease Markers
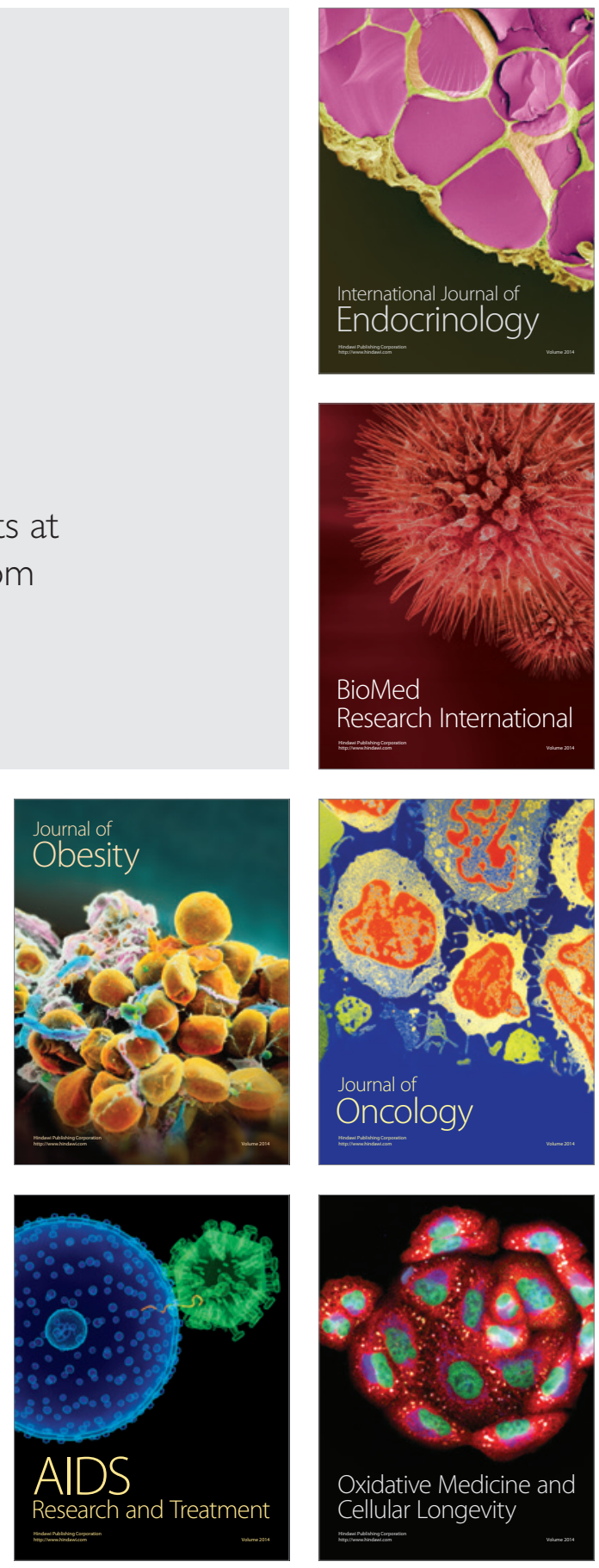